\title{
Deskripsi Keterampilam Proses Sains Dasar Siswa Kelas VIII SMP Pada Materi Cermin Cekung
}

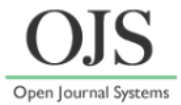

\author{
Diki Chen*, Riska Fitriani, Shella Maryani, Endah Febri Setiya \\ Rini, Wita Ardina Putri, Auliya Ramadhanti \\ Program Studi Pendidikan Fisika, Universitas Jambi, Jambi 36123 \\ *Email: dikichen012@gmail.com \\ DOI: https://doi.org/10.33369/pendipa.5.1.50-55
}

\begin{abstract}
The aim of this study was to describe the science process skills of grade VIII students of SMP (junior high school) Negeri 12 Muaro Jambi district by carrying out physics practicum activities on concave mirror material. The type of the research was descriptive quantitative. the sample used was 30 students of SMP (junior high school) Negeri 12 Muaro Jambi. The instrument used in this research was observation sheet that has been validated by the validator. The data were collected using a total sampling technique which was then analyzed using descriptive statistics. The indicators used were 6 indicators of basic science process skills, namely; observation, communication, classification, prediction, measuring, and concluding activities. The results showed that the students were good and skilled in observing, communicating, classifying, predicting, measuring, and concluding. The percentage results obtained were; observation indicators with average value of 22.7 (Good), communication indicators were 5.67 (Good), classification indicators were 3.03 $(\mathrm{Good})$, predictive indicators were 2.76 (Good), measuring indicators was 8.63 (Good), and the concluded indicator was 16.67 (Good).
\end{abstract}

Keywords: Science process skills; Practice; Concave mirror; Descriptive quantitative

\begin{abstract}
ABSTRAK
Penelitian ini bertujuan untuk mendeskripsikan keterampilan proses sains siswa kelas VIII SMP Negeri 12 Kabupaten Muaro Jambi dengan melakukan kegiatan praktikum fisika materi cermin cekung. Jenis penelitian yang digunakan adalah kuantitatif deskriptif. sampel yang digunakan sebanyak 30 siswa SMP Negeri 12 Muaro Jambi. Data penelitian ini menggunakan instrumen berupa lembar observasi yang sudah divalidasi oleh validator. Data dikumpulkan dengan teknik total sampling yang kemudian dianalisis menggunakan statistik deskriptif. Indikator yang digunakan ada 6 indikator keterampilan proses sains dasar yaitu; observasi, komunikasi, klasifikasi, prediksi, mengukur, dan menyimpulkan. Hasil penelitian diperoleh bahwa siswa sudah tergolong baik dan terampil dalam melakukan mengobservasi, mengkomunikasi, mengklasifikasi, memprediksi, mengukur, dan menyimpulkan. Hasil presentase yang diperoleh yaitu; indikator observasi diperoleh nilai rata-rata 22,7 (Baik), indikator komunikasi diperoleh sebesar 5,67 (Baik), indikator klasifikasi diperoleh sebesar 3,03 (Baik), indikator prediksi diperoleh sebesar 2,76 (Baik), indikator mengukur diperoleh sebesar 8,63 (Baik), dan indikator menyimpulkan diperoleh sebesar 16,67 (Baik).
\end{abstract}

Kata kunci: Keterampilan proses sains; Praktikum; Cermin cekung; Kuantitatif deskriptif

\section{PENDAHULUAN}

Pendidikan beserta sistemnya merupakan suatu hal yang dinamis (Mahmudah, 2019), pendidikan pada dasarnya adalah usaha sadar untuk menumbuhkembangkan potensi sumber daya manusia terutama peserta didik yang dilakukan dengan cara membimbing dan memfasilitasi proses pembelajaran mereka
(Astalini, 2018) mengacu dari hal tersebut pendidikan bukan hanya berbicara masalah membimbing tapi juga bagaimana membuat anakanak berilmu pengetahuan, terampil, dan juga kompeten dalam bidang kehidupan masyarakat. 
Berdasarkan Penelitian Afrizon, et all (2012) proses pembelajaran di sekolah mengalami banyak kendala yaitu: (1) Pembelajaran terlalu terpusat ke guru; (2) Masih banyak siswa yang mencontek dan kurang teliti dalam mengerjakan tugas (3) Kecenderungan siswa untuk menerima tanpa menelaah terlebih dahulu materi (4) Siswa kurang aktif dikelas (5) Masih terdapat siswa yang suka menertawakan siswa lain jika disuruh maju. Melihat situasi ini maka diperlukan sebuah model yang mengharuskan siswa untuk aktif dan juga dapat mengembangkan keterampilan siswa khususnya dibidang sains, salah satunya dengan melakukan praktikum.

Didalam dunia pendidikan, penelitian praktikum dimaksudkan untuk menilai/membuktikan pengaruh perlakuan pendidikan terhadap prestasi belajar siswa, dimana hal tersebut dapat diberikan bukan hanya lewat teori dan pengalaman melainkan juga keterampilan. Hal ini ditegaskan dengan adanya dorongan revolusi industri 4.0 yang mengharuskan adanya keseimbangan antara teori dan praktik dalam mempersiapkan sumber daya manusia saat ini. Oleh karena itu, keterampilan menjadi sesuatu yang sangat penting dalam menunjang kehidupan manusia. Untuk mengembangkan konsep atau teori diperlukan suatu keterampilan yang terarah dan sistematis, salah satu upaya untuk mengembangkan hal tersebut yaitu dengan melakukan keterampilan proses sains (Emda, 2014).

Keterampilan proses sains merupakan keterampilan yang sangat penting dan harus dimiliki untuk setiap siswa (Mutmainnah, 2019). Keterampilan proses sains merupakan runtutan kegiatan yang dilakukan mencari atau memproses hasil yang kemudian dijadikan pengetahuan untuk dirinya sendiri (Lestari \& Diana, 2018). Sedangkan menurut (Fitriani, 2016) keterampilan proses sains (KPS) merupakan keterampilan yang berupaya untuk mendorong sisa agar menemukan dan juga mengembangkan materi guna untuk mempermudah pengembangan kemampuan selanjutnya.
Keterampilan proses sains (KPS) merupakan sebuah kegiatan kontekstual, bertujuan untuk mendeskripsikan sesuatu dengan prosedur yang dibuat secara sistematis guna mencapai tujuan pembelajaran efektif (Daud, 2018). KPS sangat sering digunakan para ilmuan selama penelitiannya (Desstya, 2015), KPS digunakan dalam kegiatan ilmiah, salah satunya yaitu eksperimen atau praktikum. Keterampilan proses sains dibedakan menjadi dua yaitu keterampilan proses sains dasar dan keterampilan proses sains terintegrasi. Keterampilan proses dasar yaitu, observasi, pengukuran, klasifikasi, kuantifikasi, menyimpulkan, memprediksi, hubungan, mengkomunikasikan. Sedangkan untuk keterampilan proses sains terintegrasi yaitu, menafsirkan data, mengontrol variable, definisi operasional, hipotesa, percobaan.

Menurut Johani (2019) Instrumen adalah alat untuk mengambil data, indikator yang digunakan dalam penelitian ketrampilan proses sains yaitu: (1) Observasi; (2) Komunikasi; (3)

Klasifikasi; (4) Mengukur; (5) Menyimpulkan; (6) Memprediksi; (7) Identifikasi Variabel; (8) Menyusun tabel data; (9) Menyusun grafik; (10) Mendeskripsikan hubungan antar Variabel; (11) Memproses data; (12) Menganalisis Investigasi; (13) Membuat Hipotesis (14) Mendefinisikan variabel secara operasional; (15) Merancang investigasi; (16) Melakukan eksperimen.

Peran keterampilan proses sains dalam belajar mengajar sangat penting dalam perkembangan pembelajaran siswa dikelas. Bukan hanya penting bagi perkembangan belajar tetapi juga untuk kehidupan sehari-hari, dengan memiliki keterampilan proses sains diharapkan dapat menumbuhkan dan melatih berpikir kritis dan logis dalam memecahkan masalah di masyarakat. Adanya proses sains dalam pembelajaran dapat menumbuhkan rasa ingin tahu dan juga dapat mengembangkan sikap teliti, tekun dan peduli erhadap lingkungan sekitar (Zulaeha, Darmadi, \& Werdhiana, n.d). Keterampilan proses sains tidak hanya dapat diterapkan dalam proses pembelajaran dikelas, namun juga dapat diterapkan di lingkungan sekitar siswa yang menjadi bekal dalam memecahkan masalah dalam 
kehidupan sehari-hari (Rahayu \& Anggreini, 2017).

KPS mempunyai peranan penting dalam proses keingintahuan dan keilmiahan siswa, namun beberapa dari hasil penelitian didapati banyak siswa yang memiliki krisis kemampuan ilmiah yang dapat dilihat dari kemampuankinerja ilmiah siswa (Lumbu, 2018). Berdasarkan kebutuhan dan juga kelancaran proses belajar siswa pada mata pelajaran IPA terutama kompetensi ilmiahnya, maka perlu dilakukan sebuah deskripsi mengenai keterampilan proses sains dasar siswa.

\section{METODE PENELITIAN}

Metode dalam penelitian ini adalah kuantitatif deksriptif. Sampel yang digunakan adalah siswa kelas VIII SMP Negeri Kabupaten Muaro Jambi sebanyak 30 sampel siswa. Penelitian ini dilaksanakan pada November 2020. Sampel dikelompokkan menjadi 6 kelompok yang terdiri dari 5 siswa. Siswa diberi LKS dan peneliti memberikan pendahuluan dan demonstrasi singkat mengenai lensa cekung. Selanjutnya, siswa melakukan praktikum menggunakan alat yang disediakan. Teknik penelitian dilakukan dengan observasi menggunakan lembar observasi yang memuat 21 butir pernyataan tentang keterampilan proses sains dasar. Dalam observsi ini 15 orang membantu pengisian lembar observasi dan pengkondisian siswa. Data yang diperoleh dari lembar observasi diolah dan dianalisis menggunakan analisis deskriptif di SPSS. Menurut Ningsi (2020) keterampilan proses sains terbagi menjadi dua yaitu KPS dasar dan KPS terintegrasi. Pada penelitian ini keterampilan proses yang diamati yaitu keterampilan proses sains dasar. Indikator yang diamati ada 6 indikator yaitu, mengobservasi, mengkomunikasi, mengklasifikasi, memprediksi, mengukur, dan menyimpulkan. Data interval setiap indikatornya dinyatakan dalam Tabel 1, Tabel 2, Tabel 3, Tabel 4, Tabel 5, dan Tabel 6.

Tabel 1. Kategori penguasaan keterampilan sains dasar siswa pada indikator observasi

\begin{tabular}{|c|c|c|}
\hline No. & Interval & Kategori \\
\hline 1. & $8,00-14,00$ & Sangat tidak baik \\
\hline
\end{tabular}

\begin{tabular}{|c|c|c|}
\hline 2. & $\begin{array}{c}14,01- \\
20,00\end{array}$ & Tidak baik \\
\hline 3. & $20,01-$ & Baik \\
& 26,00 & \\
\hline 4. & $26,01-$ & Sangat Baik \\
& 32,00 & \\
\hline
\end{tabular}

Tabel 2. Kategori penguasaan keterampilan sains dasar siswa pada indikator komunikasi

\begin{tabular}{|c|c|c|}
\hline No. & Interval & Kategori \\
\hline 1. & $2,00-3,50$ & Sangat tidak baik \\
\hline 2. & $3,51-5,00$ & Tidak baik \\
\hline 3. & $5,01-6,50$ & Baik \\
\hline 4. & $6,51-8,00$ & Sangat Baik \\
\hline
\end{tabular}

Tabel 3. Kategori penguasaan keterampilan sains dasar siswa pada indikator klasifikasi

\begin{tabular}{|c|c|c|}
\hline No. & Interval & Kategori \\
\hline 1. & $1,00-1,75$ & Sangat tidak baik \\
\hline 2. & $1,76-2,50$ & Tidak baik \\
\hline 3. & $2,51-3,25$ & Baik \\
\hline 4. & $3,26-4,00$ & Sangat Baik \\
\hline
\end{tabular}

Tabel 4. Kategori penguasaan keterampilan sains dasar siswa pada indikator memprediksi

\begin{tabular}{|c|c|c|}
\hline No. & Interval & Kategori \\
\hline 1. & $1,00-1,75$ & Sangat tidak baik \\
\hline 2. & $1,76-2,50$ & Tidak baik \\
\hline 3. & $2,51-3,25$ & Baik \\
\hline 4. & $3,26-4,00$ & Sangat Baik \\
\hline
\end{tabular}

Tabel 5. Kategori penguasaan keterampilan sains dasar siswa pada indikator mengukur

\begin{tabular}{|c|c|c|}
\hline No. & Interval & Kategori \\
\hline 1. & $3,00-5,25$ & Sangat tidak baik \\
\hline 2. & $5,26-7,50$ & Tidak baik \\
\hline 3. & $7,51-9,75$ & Baik \\
\hline 4. & $9,76-12,00$ & Sangat Baik \\
\hline
\end{tabular}

Tabel 6. Kategori penguasaan keterampilan sains dasar siswa pada indikator menyimpulkan

\begin{tabular}{|c|c|c|}
\hline No. & Interval & Kategori \\
\hline 1. & $6,00-10,50$ & Sangat tidak baik \\
\hline 2. & $10,51-$ & Tidak baik \\
& 15,00 & \\
\hline
\end{tabular}




\begin{tabular}{|c|c|c|}
\hline 3. & $\begin{array}{c}15,01- \\
19,50\end{array}$ & Baik \\
\hline 4. & $19,51-$ & Sangat Baik \\
& 24,00 & \\
\hline
\end{tabular}

\section{HASIL DAN PEMBAHASAN}

Keterampilan proses sains (KPS) merupakan keterampilan yang berbasis inkuiri terbimbing dan umumnya dilaksanakan melalui praktikum (Sarlivanti, 2014). Pendekatan KPS lebih terfokus terhadap siswanya, semua kegiatan dirancang sedemikianrupa agar siswa melibatkan diri dalam kegiatan pembelajaran ilmiah (Dewi, 2016). Keterampilan proses sains sangat penting dalam pengembangan keterampilan lain yang lebih tinggi. Menurut Nata (2009) Siswa cenderung lebih suka menerima informasi atau pengetahuan yang sudah jadi tanpa mencari tahu bagaimana informasi itu dapat dibuat, hal ini tentunya tidak efektif dalam mencetak lulusan- lulusan yang berkualitas.

Deskripsi hasil keterampilan proses sains dasar pada materi cermin cekung di SMP Negeri 12 Muaro Jambi dapat dilihat pada tabel berikut ini:

Tabel 7. Deskripsi indikator keterampilan proses dasar siswa SMP Negeri 12 Sungai Bahar Kabupaten Muaro Jambi Materi Cermin

\begin{tabular}{|c|c|c|c|c|c|c|}
\hline \multicolumn{7}{|c|}{ Cekung } \\
\hline \multicolumn{2}{|c|}{ Klasifikasi } & \multirow[b]{2}{*}{$\%$} & \multirow[b]{2}{*}{$\mathrm{Me}$} & \multirow[b]{2}{*}{$\begin{array}{c}\mathrm{Me} \\
\mathrm{d}\end{array}$} & \multirow[b]{2}{*}{$\begin{array}{c}\mathrm{Mi} \\
\mathrm{n}\end{array}$} & \multirow[b]{2}{*}{$\begin{array}{c}\mathrm{Ma} \\
\mathrm{X}\end{array}$} \\
\hline $\begin{array}{c}\text { Indika } \\
\text { tor }\end{array}$ & $\begin{array}{c}\text { Kat } \\
\text { ego } \\
\text { ri }\end{array}$ & & & & & \\
\hline \multirow{4}{*}{$\begin{array}{l}\text { Meng } \\
\text { obser } \\
\text { vasi }\end{array}$} & STB & 0 & \multirow{5}{*}{$\begin{array}{c}22 \\
7\end{array}$} & \multirow{5}{*}{22} & \multirow{5}{*}{17} & \multirow{5}{*}{28} \\
\hline & TB & 13,3 & & & & \\
\hline & B & 80,0 & & & & \\
\hline & SB & 6,7 & & & & \\
\hline Total & & 100 & & & & \\
\hline \multirow{4}{*}{$\begin{array}{c}\text { Meng } \\
\text { Komu } \\
\text { nikasi } \\
\text { kan }\end{array}$} & STB & 0 & \multirow{5}{*}{$\begin{array}{c}5,6 \\
7\end{array}$} & \multirow{5}{*}{6} & \multirow{5}{*}{4} & \multirow{5}{*}{8} \\
\hline & TB & 46,7 & & & & \\
\hline & $\mathrm{B}$ & 23,3 & & & & \\
\hline & SB & 30,0 & & & & \\
\hline \multirow[t]{3}{*}{ Total } & & 100 & & & & \\
\hline & STB & 10,0 & \multirow{2}{*}{$\begin{array}{c}3,0 \\
3\end{array}$} & \multirow{2}{*}{3} & \multirow{2}{*}{1} & \multirow{2}{*}{4} \\
\hline & TB & 13,3 & & & & \\
\hline
\end{tabular}

\begin{tabular}{|c|c|c|c|c|c|c|}
\hline \multirow{2}{*}{$\begin{array}{l}\text { Mengl } \\
\text { asifik } \\
\text { asikan }\end{array}$} & B & 40,0 & & & & \\
\hline & SB & 36,7 & & & & \\
\hline Total & & 100 & & & & \\
\hline \multirow{4}{*}{$\begin{array}{l}\text { Memp } \\
\text { rediks } \\
\quad \text { i }\end{array}$} & STB & 6,7 & \multirow{5}{*}{$\begin{array}{c}2,7 \\
6\end{array}$} & \multirow{5}{*}{3} & \multirow{5}{*}{1} & \multirow{5}{*}{4} \\
\hline & TB & 33,3 & & & & \\
\hline & B & 36,7 & & & & \\
\hline & SB & 23,3 & & & & \\
\hline Total & & 100 & & & & \\
\hline \multirow{4}{*}{$\begin{array}{c}\text { Meng } \\
\text { ukur }\end{array}$} & STB & 0 & \multirow{5}{*}{$\begin{array}{c}8,6 \\
3\end{array}$} & \multirow{5}{*}{8} & \multirow{5}{*}{6} & \multirow{5}{*}{11} \\
\hline & TB & 10,0 & & & & \\
\hline & B & 70,0 & & & & \\
\hline & SB & 20,0 & & & & \\
\hline Total & & 100 & & & & \\
\hline \multirow{4}{*}{$\begin{array}{l}\text { Menyi } \\
\text { mpulk } \\
\text { an }\end{array}$} & STB & 0 & \multirow{5}{*}{$\begin{array}{c}16, \\
67\end{array}$} & \multirow{5}{*}{17} & \multirow{5}{*}{14} & \multirow{5}{*}{22} \\
\hline & TB & 26,6 & & & & \\
\hline & B & $\begin{array}{c}1 \\
66,6 \\
7\end{array}$ & & & & \\
\hline & SB & 6,7 & & & & \\
\hline Total & & 100 & & & & \\
\hline
\end{tabular}

Tabel 7 menunjukkan presentase keterampilan proses sains dasar dari 30 sampel siswa. Dari data didapatkan sebanyak 6,7\% siswa memiliki keterampilan mengobservasi yang sangat baik, untuk kelima indikator lainnya berturut turut memiliki indikator sangat baik (SB) sebesar; mengkomunikasikan (30\%), mengklasifikasi $(36,7 \%)$, memprediksi $(23,3 \%)$, mengukur (20\%), dan menyimpulkan (6,7\%).

Dari hasil penelitian, diperoleh hasil keterampilan proses siswa terhadap materi lensa cekung sudah baik, hal ini dapat dilihat bahwa sebagian besar siswa. Pada Indikator observasi diperoleh presentase TB sebesar 13,3\%, hal ini menunjukkan bahwa sebagian besar siswa sudah terampil dalam melakukan observasi sebelum melakukan praktikum, dimana indikator ini dapat dilihat saat siswa mengamati alat dan bahan yang digunakan dalam praktikum cermin cekung, mengamati letak bayangan benda, mengamati bayangan benda pada layar, mengamati sifat bayangan benda yang terbentuk, mengamati jarak bayangan, mengamati jarak benda, mengamati jarak titik fokus, dan mengamati data dalam tabel untuk membuat grafik hubungan variabel pada percobaan pada cermin cekung. 
Pada indikator komunikasi diperoleh presentase TB yang cukup besar yaitu 46,7\%, hal ini menunjukkan bahwa sebagian besar siswa belum terbiasa melakukan interaksi antar sesama anggota kelompoknya saat praktikum, indikator ini dapat dilihat saat siswa mendiskusikan hasil pengukuran dengan teman sekelompoknya dan mempresentasikan hasil percobaan.

Pada indikator klasifikasi didapatkan presentase STB dan TB yang tidak terlalu besar yaitu $10 \%$ dan $13,3 \%$, hal ini menunjukkan siswa sudah mampu mengklasifikasikan karakteristik percobaan yang terlihat dalam pembuatan tabel. Indikator ini dapat dilihat pada saat siswa mengklasifikasikan karakteristik data percobaan yang termuat dalam pembuatan tabel.

Pada indikator prediksi didapatkan didapatkan presentase yang lumayan berimbang yaitu 40\% (akumulatif dari STB dan TB) dan 60\% (akumulatif dari SB dan B), hal ini menunjukkan bahwa keterampilan siswa dalam memprediksi lumayan beragam sehingga menyebabkan $40 \%$ dari jumlah sampel mengalami miss hipotesis. Indikator ini dapat dilihat saat siswa sedang membuat prediksi jika benda digeser mendekati atau menjauhi benda.

Pada Indikator mengukur didapatkan presentase $10 \%$ siswa yang tidak terlalu terampil dalam melakukan praktikum, hal ini menujukkan bahwa sebagian besar siswa sudah paham prosedur yang diberiakan oleh peneliti. Indikator ini dapat dilihat pada saat siswa mengukur jarak benda ke cermin, mengukur jarak bayangan ke cermin, dan mengukur jarak titik fokus.

Pada indikator terakhir yaitu indikator menyimpulkan didapatkan $6,7 \%$ siswa yang sudah sangat sesuai dengan keinginan peneliti, 66,67\% tepat tapi masih ada yang kurang dalam menyimpulkan kegiatan praktikum, dan 26,67\% kurang tepat dalam menyimpulkan kegiatan praktikum. Indikator ini dapat dilihat pada saat siswa mengutarakan sifat-sifat bayangan yang terbentuk di cermin cekung, mengutarakan hubungan antara jarak benda dan jarak bayangan yang terbentuk oleh cermin cekung, mengutarakan nilai jarak bayangan yang dibentuk oleh cermin cekung, mengutarakan nilai jarak benda ke cermin cekung, mengutarakan besar nilai jarak titik fokus, dan mengaitkan hasil praktek dengan teori.

\section{KESIMPULAN}

Berdasarkan penelitian diatas, dapat disimpulkan bahwa keterampilan proses sains dasar memiliki presentase yang cukup tinggi. Berdasarkan analisis, untuk indikator observasi diperoleh nilai rata-rata 22,7 (Baik), indikator komunikasi diperoleh 5,67 (Baik), indikator klasifikasi diperoleh 3,03 (Baik), indikator prediksi diperoleh 2,76 (Baik), indikator mengukur diperoleh 8,63 (Baik), dan indikator menyimpulkan diperoleh 16,67 (Baik). Dari hasil yang diperoleh dapat disimpulkan bahwa siswa SMP Negeri 12 Muaro Jambi memiliki keterampilan proses sains dasar yang baik.

\section{DAFTAR PUSTAKA}

Afrizon, R., Ratnawulan, \& Fauzi, A. (2012). Peningkatan Perilaku Berkarakter Dan Keterampilan Berpikir Kritis Siswa Kelas Ix Mtsn Model Padang Pada Mata Pelajaran Ipa-Fisika Menggunakan Model Problem Based Instruction. Jurnal Penelitian Pembelajaran Fisika, 1, 1-16.

Astalini, Kurniawan, D. A., Sumaryanti.(2018). Sikap Siswa Terhadap Pelajaran Fisika Di SMAN Kabupaten Batanghari. Jurnal Ilmu Pendidikan Fisika, 3(2), 59.

Daud, Muhammad. (2018). Efektivitas Pembelajaran Keterampilan Proses Sains (Kps) Pada Pokok Bahasan Termo Kimia Dalam Meningkatkan Kemampuan Siswa Di SMA Negeri 1 Krueng Barona Jaya Kabupaten Aceh Besar Dinas Pendidikan Aceh. Lantanida Journal, 6(1), 92.

Desstya, Anatri. (2015). Keterampilan Proses Sains Dan Pembelajaran Ipa Di Sekolah Dasar (Telaah Buku Siswa Kelas Iv Sd Tema 2 Karya Sumini). Jurnal Profesi Pendidikan Dasar, 2(2), 96.

Emda, Amna. (2014). Laboratorium Sebagai Sarana Pembelajaran Kimia Dalam Meningkatkan Pengetahuan Dan Ketrampilan Kerja Ilmiah. Lantanida Journal, 2(2), 222. 
Fitriani, M. S., Saminan, Elisa. (2016). Penerapan Keterampilan Proses Sains (KPS) Dalam Meningkatkan Hasil Belajar Tekanan Zat Cair Pada Sisa MTsN Kuta Baro Aceh Besar. Jurnal Ilmiah Mahasiswa Pendidikan Fisika, 1(4).

Johani, Azhami, dan Heldalia. (2019). Implementasi Karakter Tanggung Jawab Kelas VIIE dan VIIH SMP Negeri 7 Muaro Jambi. Jurnal Profesi Keguruan, 5(2), 125.

Lestari, M. Y., dan Diana, N. (2018). Keterampilan proses sains (KPS) pada pelaksanaan Praktikum fisika dasar I. Indonesian Journal of Science and Mathematics Education, 1(1).

Lumbu, Albert., dan Panda, F. M. (2018). Peningkatan Keterampilan Proses Sains Dasar Dalam Menggunakan Alat Ukur Pada Pembelajaran Fisika Di Sma Negeri 6 Skouw Jayapura. Jurnal Pengabdian Рapua, 2(2), 40.

Mahmudah, I. R., Makiyah, Y. S., Sulistyaningsih, D. (2019). Profil Keterampilan Proses Sains (KPS) Siswa SMA di Kota Bandung. Diffraction, 1(1), 39.

Mutmainnah, S. F., Padmawati, K., Puspitasari, N., Prayitno, B. A. (2019). Profil Keterampilan Proses Sains (KPS) Mahasiswa Pendidikan Biologi Ditinjau Dari Kemampuan Akademik (Studi Kasus Di Salah Satu Universitas Di Surakarta). Jurnal Penelitian Pendidikan Biologi, 3(1), 50 .
Nata, Abuddin. (2009). Perspektif Islam Tentang Strategi Pembelajaran. Jakarta: Kencana

Ningsi, A. P., dan Nasih, N. R. (2020). Mendeskripsikan Keterampilan Proses Sains Siswa Pendidikan Fisika Universitas Jambi Pada Materi Pembiasan Pada Lensa Cembung Dengan Menggunakan E-Modul. Jurnal Penelitian Dan Pembelajaran IPA, 5(2), 38.

Rahayu, A. H., dan Anggraeni, Poppy. (2017). Analisis Profil Keterampilan Proses Sains Siswa Sekolah Dasar Di Kabupaten Sumedang. Jurnal Pesona Dasar, 5(2), 23.

Sarlivanti, Adlim, Djailani. (2014). Pembelajaran Praktikum Berbasis Inkuiri Terbimbing untuk Meningkatkan Keterampilan Berpikir Kritis dan Keterampilan Proses Sains pada Pokok Bahasan Larutan Penyangga. Jurnal Pendidikan Sains Indonesia, 2(1), 76.

Zulaeha, Darmadi, I. W., Werdhiana. (n.d.). Pengaruh Model Pembelajaran Predict, Observe and Explain terhadap Keterampilan Proses Sains Siswa Kelas X SMA Negeri 1 Balaesang. Jurnal Pendidikan Fisika, 2(2), 1-8. 